\title{
EVALUASI PENGGUNAAN ANTIBIOTIK PNEUMONIA DENGAN METODE ATC/DDD PADA PASIEN PEDIATRI DI INSTALASI RAWAT INAP RSUD. DR. A. DADI TJOKRODIPO BANDAR LAMPUNG TAHUN 2019
}

\section{EVALUATION OF PNEUMONIA ANTIBIOTIC USING ATC/DDD METHOD FOR PEDIATRIC PATIENTS IN INSTALLATION OF HOSPITAL. DR. A. DADI TJOKRODIPO BANDAR LAMPUNG IN 2019}

\author{
Lilik Koernia Wahidah, Novita Tri Wahyuni, Deska Maharani Putri \\ Fakultas MIPA, Program Studi Farmasi, Universitas Tulang Bawang \\ Email : lilik.kw260682@gmail.com \\ HP. 0813-6906-0708
}

\begin{abstract}
Pneumonia is an inflammation of the lungs that causes pain during breathing and limited oxygen intake. Antibiotics are the main therapy for pneumonia, appropriate and rational antibiotic therapy will determine the success of treatment to avoid bacterial resistance. The purpose of this study was to evaluate the use of pneumonia antibiotics in pediatric patients with the ATC / DDD method in pediatric patients in the Hospital Dr. Hospital. A. Dadi Tjokrodipo Bandar Lampung in 2019. This research is descriptive in nature with retrospective data collection. The sampling technique used was purposive sampling with a sample size of 70 patients with pediatric pneumonia. The data obtained were analyzed by using ATC / DDD and DU 90\% methods. The results showed that from 70 samples studied, it was found that the patient characteristics were based on gender, namely $61.42 \%$ of them were male and based on age, namely $65.71 \%$ were infant patients aged 1 month - 2 years. The total use of antibiotics was 65.92 DDD / 100 days of hospitalization and antibiotics that entered the 90\% DU segment, namely ampicillin (27.53 DDD / 100 days of hospitalization), gentamicin (8.39 DDD / 100 days of hospitalization), azithromycin (7, 13 DDD / 100 days of care), amoxicillin (6.88 DDD / 100 days of hospitalization) and ampicillin sulbactam (6.6 DDD / 100 days of hospitalization). Then evaluated the use of antibiotics and the results were 100\% correct, 100\% correct indication, 57.4\% correct dose and $100 \%$ correct time interval of administration. The use of antibiotic pneumonia in Dr. A. Dadi Tjokrodipo still needs to be improved again, especially regarding the administration of antibiotic doses.
\end{abstract}

Keywords: Antibiotics, ATC, DDD, Pediatrics, Pneumonia. 


\begin{abstract}
ABSTRAK
EVALUASI PENGGUNAAN ANTIBIOTIK PNEUMONIA DENGAN METODE ATC/DDD PADA PASIEN PEDIATRI DI INSTALASI RAWAT INAP RSUD. DR. A. DADI TJOKRODIPO BANDAR LAMPUNG TAHUN 2019
\end{abstract}

\begin{abstract}
Pneumonia adalah peradangan paru yang menyebabkan nyeri saat bernafas dan keterbatasan intake oksigen. Antibiotik merupakan terapi utama pneumonia, terapi antibiotik yang tepat dan rasional akan menentukan keberhasilan pengobatan untuk menghindari terjadinya resistensi bakteri. Tujuan penelitian ini adalah untuk mengevaluasi penggunaan antibiotik pneumonia pada pasien pediatri dengan metode $A T C / D D D$ pada pasien pediatri di Instalasi Rawat Inap RSUD Dr. A. Dadi Tjokrodipo Bandar Lampung tahun 2019. Penelitian ini bersifat deskriptif dengan pengumpulan data secara retrospektif. Teknik sampling yang digunakan metode adalah purposive sampling dengan jumlah sampel 70 pasien pneumonia pediatri. Data yang diperoleh dianalisis dengan metode $A T C / D D D$ dan DU 90\%. Hasil penelitian menunjukan dari 70 sample yang diteliti, didapatkan karakteristik pasien berdasarkan jenis kelamin yaitu 61,42\% diantaranya adalah berjenis kelamin laki-laki serta berdasarkan usia yaitu $65,71 \%$ adalah pasien bayi dengan usia 1 bulan - 2 tahun. Total penggunaan antibiotik yaitu 65,92 DDD/100 hari rawat inap dan antibiotik yang masuk kedalam segmen DU $90 \%$ yaitu ampisilin $(27,53$ $\mathrm{DDD} / 100$ hari rawat), gentamisin (8,39 DDD/100 hari rawat), azitromisin (7,13 DDD/100 hari rawat), amoksisilin (6,88 DDD/100 hari rawat) dan ampisilin sulbaktam (6,6 DDD/100 hari rawat). Lalu dilakukan evaluasi penggunaan antibiotic dan didapatkan hasil yaitu tepat pasien $100 \%$, tepat indikasi $100 \%$, tepat dosis $57,4 \%$ dan tepat interval waktu pemberian 100\%. Penggunaan antibiotik pneumonia di RSUD Dr. A. Dadi Tjokrodipo ini masih perlu ditingkatkan kembali, khususnya menyangkut pemberian dosis antibiotik.
\end{abstract}

Kata kunci : Antibiotik, ATC, DDD, Pediatri,Pneumonia,.

\section{PENDAHULUAN}

Pneumonia merupakan salah satu penyakit ISPA pada anak yang menyumbang $15 \%$ dari semua kematian anak dibawah 5 tahun, yang menewaskan 808.694 anak di seluruh dunia pada tahun 2017. Terdapat 15 negara dengan insidens pneumonia anak balita paling tinggi, mencakup $74 \%$ (115,3 juta) dari 156 juta kasus di seluruh dunia. Lebih dari setengahnya terdapat di 6 negara, mencakup 44\% populasi anak di dunia(1).

Pada tahun 2018 penderita pneumonia di Indonesia berkisar $2 \%$ dari populasi balita dan dengan jumlah penderita pneumonia balita di provinsi Lampung usia dibawah 1 tahun berjumlah 2356 balita dan usia 1-4 tahun berjumlah 5732 balita. Sehingga seluruhnya berjumlah 8088 balita atau sekitar $1,69 \%$ dari total jumlah penemuan kasus pneumonia balita di Indonesia(2).

Pneumonia adalah peradangan paru yang menyebabkan nyeri saat bernafas dan keterbatasan intake oksigen. Pneumonia dapat disebarkan dengan berbagai cara antara lain pada saat batuk dan bersin(3). Antibiotik merupakan terapi utama pneumonia yang disebabkan bakteri. Antibiotik yang disarankan sebagai terapi empirik pneumonia rawat inap antara lain 
sefalosporin generasi ketiga

dikombinasikan dengan antibiotik lain nya. Pemilihan penggunaan antibiotik pada pasien bersifat individual baik dengan pengobatan tunggal maupun dengan pengobatan kombinasi(4).

Berbagai studi menemukan bahwa sekitar 40 sampai $62 \%$ pengunaan antibiotik tidak tepat antara lain untuk penyakit yang sebenarnya tidak memerlukan antibiotik. Penggunaan obat yang rasional oleh pasien pneumonia merupakan salah satu bagian penting dalam tercapainya kualitas kesehatan. Pengunaan obat dikatakan rasional apabila memenuhi kriteria tepat diagnosis, tepat indikasi, tepat pemilihan obat, tepat dosis, tepat cara pemberian dan tepat lama pemberian(5).

Banyaknya penyebab infeksi pneumonia, pemilihan dan penggunaan terapi antibiotik yang tepat dan rasional akan menentukan keberhasilan pengobatan untuk menghindari terjadinya resistensi bakteri. Perlu dilakukan suatu penelitian untuk mengevaluasi penggunaan antibiotik pada kasus pneumonia lebih lanjut. Evaluasi penggunaan obat dapat dilakukan dengan menggunakan metode ATC/DDD dimana metode ini direkomendasikan oleh WHO untuk mengevaluasi penggunaan obat. Metode ini dilakukan dengan cara melakukan perhitungan DDD yang digunakan per 100 hari rawat yang bertujuan untuk mengevaluasi jenis dan antibiotik yang digunakan(6).

Penelitian ini bertujuan untuk mengevaluasi penggunaan antibiotik pneumonia pada pasien pediatri dengan metode ATC/DDD di Instalasi Rawat Inap RSUD Dr. A. Dadi Tjokrodipo Bandar Lampung.

\section{METODE PENELITIAN}

Penelitian ini bersifat deskriptif, pengumpulan data dilakukan secara retrospektif dengan menggunakan data rekam medis pasien pediatri pneumonia di RSUD. Dr. A Dadi Tjokrodipo. Teknik pengambilan sample pada penelitian ini menggunakan metode purposive sampling. Lalu kemudian dilakukan pencatatan berupa insial nama pasien, umur, jenis kelamin, berat badan, diagnosa pasien, dan terapi yang diterima. Data - data tersebut kemudian dianalisis berdasarkan terapi antibiotik nyadengan menggunakan metode ATC/DDD dan DU $90 \%$ lalu setelah itu dilakukan evaluasi ketepatan berdasarkan tepat dosis, tepat pasien, tepat indikasi dan tepat interval waktu pemberian obat.

\section{Lokasi dan Waktu Penelitian}

Penelitian ini dilakukan di RSUD Dr. A. Dadi Tjokrodipo Bandar Lampung dan pengambilan data dilakukan pada bulan mei 2020.

\section{Populasi dan Sampel}

Populasi untuk penelitian ini adalah seluruh data pasien pediatri pneumonia yang menggunakan antibiotik di Instalasi Rawat Inap RSUD Dr. A. Dadi Tjokrodipo yang tercatat dari bagian Rekam Medik selama tahun 2019. Sampel yang digunakan dalam penelitian ini adalah sebagian pasien pediatri pneumonia yang tercatat dari bagian rekam medik yang menggunakan antibiotik serta memenuhi kriteria inklusi. Pengambilan sampel dengan menggunakan rumus slovin, setelah dilakukan perhitungan didapatkan sampel berjumlah 70 pasien dari jumlah populasi yaitu 235 pasien.

\section{Instrumen dan Pengolahan Data}

Instrumen pada penelitian ini adalah menggunakan data rekam medik pasien untuk mengetahui hasil diagnosa dokter bahwa pasien tersebut mengalami pneumonia, mengetahui identitas dan informasi mengenai obat yang diberikan kepasien yang termasuk pada periode 2019. 
Data yang sudah dikumpulkan kemudian diolah ke dalam tabel rekapitulasi sesuai dengan variabel yang telah ditentukan.

\section{HASIL DAN PEMBAHASAN}

Berdasarkan penelitian yang telah dilakukan, peneliti mengambil data rekam medik berjumlah 70 yang berasal dari keseluruhan populasi yang berjumlah 235, maka didapatkan gambaran karakteristik pasien pediatrik sebagai berikut.

\section{Umur}

Berikut ini adalah diagram gambaran karakteristik pasien berdasarkan umur

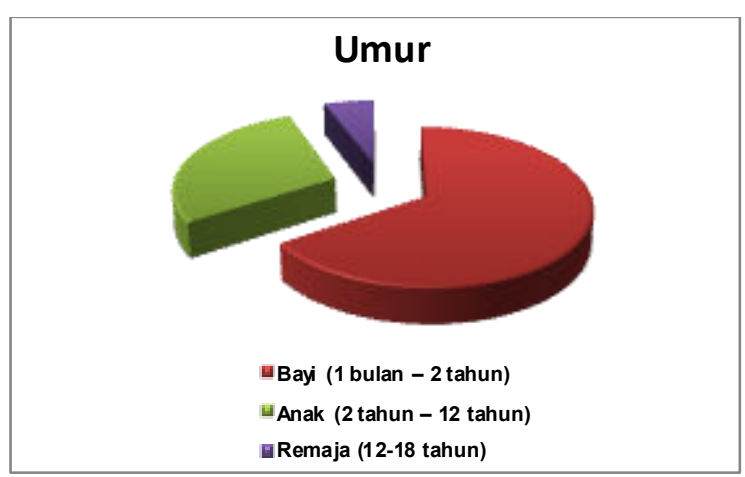

Gambar 1. Diagram gambaran pasien pediatrik berdasarkan umur.

Pada gambar 1 diatas terdapat pasien bayi berjumlah 46 pasien $(65,17 \%)$, pasien anak berjumlah 20 pasien $(28,57$ $\%$ dan pasien remaja berjumlah 4 pasien $(5,71 \%)$.

Kasus pneumonia terbanyak terjadi pada pasien bayi disebabkan karna sistem imun yang belum sempurna, selain itu banyaknya bayi yang terinfeksi dapat karna adanya transmisi dari ibu ke anak yang berhubungan pada saat proses persalinan dan adanya kontak fisik dari pasien yang terinfeksi(7).

\section{Jenis Kelamin}

Berikut ini adalah diagram gambaran karakteristik pasien berdasarkan jenis kelamin

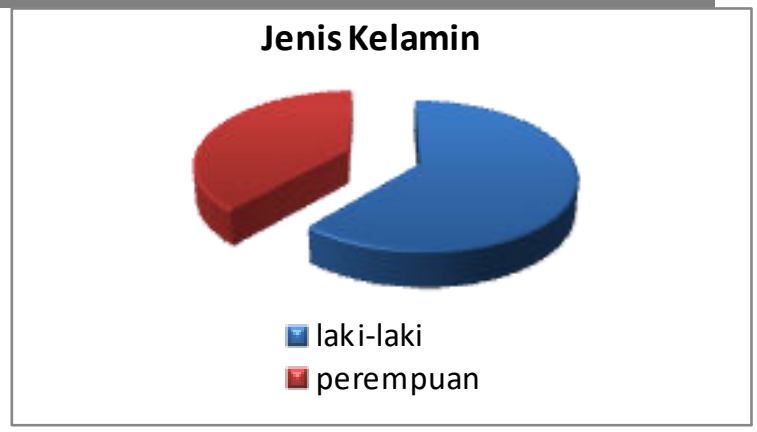

Gambar 2. Diagram gambaran pasien pediatrik berdasarkan jenis kelamin.

Pada Gambar 2 diatas, terdapat pasien dengan jenis kelamin laki - laki berjumlah 43 pasien $(61,42 \%)$ dan perempuan berjumlah 27 pasien $(38,57$ $\%)$.

Kasus pneumonia terbanyak terjadi pada pasien pediatri dengan jenis kelamin lakilaki. Anak dengan jenis kelamin laki-laki memiliki tingkat resiko terkena penyakit pneumonia dua kali lebih tinggi dibandingkan perempuan. Anak laki-laki adalah faktor resiko yang mempengaruhi kesakitan pneumonia. Hal ini disebabkan karena diameter saluran pernafasan anak laki-laki lebih kecil dibandingkan dengan anak perempuan atau adanya perbedaan daya tahan tubuh anak lakilaki dan perempuan(8).

\section{Penggunaan Antibiotik}

Tabel 1. Terapi Antibiotik

\begin{tabular}{lcc} 
Nama antibiotik & Jumlah & $\begin{array}{c}\text { Persentase } \\
(\mathbf{n}=\mathbf{7 0})\end{array}$ \\
\hline Cefotaxime & 17 & $24,28 \%$ \\
\hline Ampisilin & 9 & $12,85 \%$ \\
\hline Ampisilin sulbaktam & 3 & $4,28 \%$ \\
\hline Azytromisin & 7 & $10 \%$ \\
\hline Amoxcillin & 2 & $2,85 \%$ \\
\hline Eritromisin & 1 & $1,42 \%$ \\
\hline Ceftriaxon & 1 & $1,42 \%$ \\
\hline $\begin{array}{l}\text { Ampisilin sulbaktam } \\
+ \text { Gentamicin }\end{array}$ & 12 & $17,14 \%$ \\
\hline $\begin{array}{l}\text { Ampisilin }+ \\
\text { Gentamicin }\end{array}$ & 8 & $11,42 \%$ \\
\hline $\begin{array}{l}\text { Anpisilin sulbaktam }+ \\
\text { Amoxicillin }\end{array}$ & 3 & $4,28 \%$ \\
\hline $\begin{array}{l}\text { Ampisilin }+ \\
\text { Amoxicillin }\end{array}$ & 1 & $1,42 \%$ \\
\hline $\begin{array}{l}\text { Ampisilin }+ \\
\text { Cefotaxime }\end{array}$ & 1 & $1,42 \%$ \\
\hline Cefotxime + & 1 & $1,42 \%$
\end{tabular}




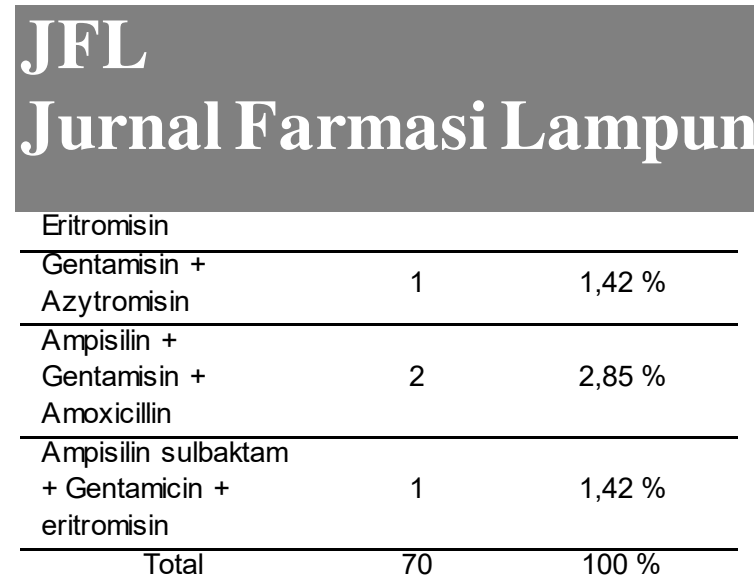

Berdasarkan tabel 1 menunjukan bahwa antibiotik tunggal dengan pemakaian terbanyak adalah cefotaxime yang digunakan oleh 17 pasien $(24,28 \%)$, lalu diikuti ampisilin yaitu 9 pasien (12,85\%). Sedangkan untuk pemakaian antibiotik kombinasi terbanyak yaitu ampisilin sulbaktam dan gentamicin yang digunakan oleh12 pasien (17,14\%), lalu diikuti dengan kombinasi ampisilin dan gentamisin yang digunakan oleh 8 pasien $(11,42 \%)$.

Antibiotik tunggal dengan pemakaian terbanyak pertama adalah sefotaksime. Sefotaksime digunakan sebagai terapi empirik yang diresepkan untuk bayi dan anak penderita pneumonia dan dirawat di rumah sakit serta pilihan obat antibiotik untuk pasien yang telah resisten dengan penisilin(9). Antibiotik sefotaksim digunakan sebagai pengobatan pneumonia apabila pasien tidak bisa mendapatkan obat secara oral atau pneumonia dengan derajat berat sampai sangat berat. Penggunaan antibiotik sefotaksim apabila dicurigai terdapat bakteri Haemophilus influenzae(10).

Urutan kedua jenis sediaan kombinasi adalah ampisilin sulbaktam dan gentamisin, ampisilin merupakan antibiotik yang dianjurkan untuk terapi empirik pada anak. Untuk menghindari terjadinya resistensi, ampisilin tidak boleh digunakan oleh pasien di rumah sakit tanpa adanya pemeriksaan(11).

Beberapa jurnal dialporkan bahwa mulai terjadi resistensi terhadap antibiotik golongan betalaktam, karnanya kombinasi betalaktam memegang peranan penting untuk mempertahankan

kegunaan agen betalaktam, dan salah satu yg disarankan adalah ampisilin sulbaktam(12).

Sulbaktam sebagai penghambat betalaktamse secara struktur mirip dengan penisilin tetapi mempunyai rantai samping yang dimodifikasi yang memungkinkan untuk berperan sebagai penghambat beraitan secara ireversibel dengan betalaktamse dan membuatnya tidak aktif. Oleh karna itu pemecahan antibiotik oleh betalaktamse dapat dicegah dan aktivitas bakterisidal dapat dipertahankan(12).

Antibiotik gentamisin adalah antibiotik golongan aminoglikosida, antibiotik golongan ini (gentamisin) dikombinasikan, apabila terdapat bakteri gram positif pada antibiotik lainya sehingga menghasilkan efek yang sinergis. Tujuan penggunaan obat kombinasi adalah memperluas spektrum anti kuman dengan kondisi kritis atau dengan infeksi berat dan mengatasi adanya kuman yang resisten(10).

Kombinasi gentamisin dan ampisilin menghasilkan efek bakterisida yang kuat, yang sebagian disebabkan oleh peningkatan ambilan obat yang timbul karna penghambatan sintesis dinding sel. Penisilin mengubah struktur dinding sel sehingga memudahkan penetrasi gentamicin pada kuman(4).

\section{Penggunaan Non-Antibiotik}

Tabel 2 Penggunaan Non-Antibiotik

\begin{tabular}{lcc} 
Nama Obat & Jumlah & $\begin{array}{c}\text { Persentase } \\
(\mathbf{n}=\mathbf{7 0})\end{array}$ \\
\hline Paracetamol & 59 & $84,28 \%$ \\
\hline Ambroxol & 49 & $70 \%$ \\
\hline Nebu ventolin & 1 & $1,42 \%$ \\
\hline Salbutamol & 4 & $5,71 \%$ \\
\hline Ondansetron & 8 & $11,42 \%$ \\
\hline Domperidon & 2 & $2,85 \%$ \\
\hline Cetirizin & 15 & $21,42 \%$ \\
\hline Chlorpheniramin Maleat & 2 & $2,85 \%$
\end{tabular}




\begin{tabular}{lcc} 
Lacto B & 13 & $18,57 \%$ \\
\hline Zink & 11 & $15,71 \%$ \\
\hline Vitamin C & 4 & $8,57 \%$ \\
\hline Caviplex & 9 & $12,85 \%$ \\
\hline Curbexon/Ferlin & 3 & $4,28 \%$ \\
\hline Methyl Prednisolone & 8 & $11,42 \%$ \\
\hline Dexametasone & 15 & $21,42 \%$ \\
\hline Omeprazole & 6 & $8,57 \%$ \\
\hline Diazepam & 3 & $4,28 \%$ \\
\hline Fenitoin & 1 & $1,42 \%$
\end{tabular}

Berdasarkan tabel 2 dapat dilihat penggunaan obat non-antibiotik yaitu paracetamol digunakan oleh 59 pasien $(84,28 \%)$, ambroxol digunakan oleh 49 pasien $(70 \%)$, cetirizin digunakan oleh 15 pasien $(21,42 \%)$, dexametasone digunakan oleh 15 pasien $(21,42 \%)$ lalu diikuti oleh obat - obat lain yang tertera pada tabel diatas.

Pengunaan non antibiotik sebagai terapi pendukung yang paling banyak yaitu obat paracetamol yang merupakan golongan analgetik antipiretik. Pemberian analgesik antipiretik bertujuan sebagai pereda demam sehingga suhu tubuh pasien dapat turun dengan pemberian paracetamol. Demam sangat umum terjadi pada orang yang menderita infeksi saluran pernafasan akut(13).

Pemberian mukolitik berupa ambroksol bertujuan untuk meringankan gejala batuk. Gejala batuk merupakan tanda adanya gangguan pada saluran pernafasan yang diikuti dengan produksi sputum dan rsa nyeri, pada kasus pneumonia gejala batuk adalah sesuatu yang normal terjadi untuk membersihkan saluran pernafasan yang disebabkan adanya benda asing atau organisme yang mengganggu pernafasan(6).

Pemberian kortikosteroid berupa deksamethason bermanfaat untuk mengurangi inflamasi yang timbul di paru-paru selama terjadinya infeksi. Penggunaan klinik kortikosteroid sebagai antiinflamasi merupakan terapi paliatif yaitu hanya gejalanya yang dihambat

sedangkan penyebab penyakitnya tetap ada(10).

\section{Klasisikasi antibiotik}

Tabel 3 Klasifikasi Antibiotik

Total

Kode ATC Antibiotik Bentuk sediaan penggunaa n

\begin{tabular}{|c|c|c|c|}
\hline J01CA01 & Ampisilin & Injeksi & 152 gram \\
\hline J01CR01 & $\begin{array}{l}\text { Ampisilin+ } \\
\text { sulbaktam }\end{array}$ & Injeksi & 109,4 gram \\
\hline \multirow{2}{*}{ J01CA04 } & \multirow{2}{*}{ Amoksisilin } & Tablet $500 \mathrm{mg}$ & 22,5 gram \\
\hline & & $\begin{array}{l}\text { Sirup } 60 \mathrm{ml}(125 \\
\mathrm{mg} / 5 \mathrm{ml})\end{array}$ & 4 botol \\
\hline J01DD01 & Cefotaxime & Injeksi & 70,1 gram \\
\hline J01DD04 & Ceftriaxon & Tnjeksi & 2,5 gram \\
\hline \multirow[b]{2}{*}{ J01FA10 } & \multirow[b]{2}{*}{ Azitromisin } & Kapssul 500 mg & 3,5 gram \\
\hline & & $\begin{array}{l}\text { Sirup Kering } 15 \\
\text { ml (200 mg/ } 5 \\
\text { ml) }\end{array}$ & 4 botol \\
\hline J01FA01 & Eritromisin & $\begin{array}{l}\text { Sirup Kering } 60 \\
\mathrm{ml}(200 \mathrm{mg} / 5 \\
\mathrm{ml})\end{array}$ & 3 botol \\
\hline J01GB03 & Gentamicin & Injeksi & 5,56 gram \\
\hline
\end{tabular}

\section{Kuantitas penggunaan antibiotik dengan DDD/100 hari rawat}

Tabel 4 DDD/100 hari rawat

\begin{tabular}{llccc} 
Kode ATC & Antibiotik & $\begin{array}{c}\text { DDD } \\
\text { Definitif }\end{array}$ & $\begin{array}{c}\text { DDD } \\
\text { penggu } \\
\text { naan }\end{array}$ & $\begin{array}{c}\text { DDD/10 } \\
\text { o hari } \\
\text { raw at }\end{array}$ \\
\hline J01CA01 & Ampisilin & 2 & 76 & 27,53 \\
\hline J01GB03 & Gentamicin & 0,24 & 23,16 & 8,39 \\
\hline J01FA10 & Azitromisin & 0,3 & 19,7 & 7,13 \\
\hline J01CA04 & Amoksisilin & 1,5 & 19 & 6,88 \\
\hline J01CR01 & Ampisilin+sulb & 6 & 18,23 & 6,6 \\
& aktam & & & \\
\hline J01DD01 & Cefotaxime & 4 & 17,5 & 6,34 \\
\hline J01FA01 & Eritromisin & 1 & 7,2 & 2,6 \\
\hline J01DD04 & Ceftriakson & 2 & 1,25 & 0,45 \\
\hline & Total DDD/100 hari raw at & & $\mathbf{6 5 , 9 2}$
\end{tabular}


Pada penelitian ini ditemukan total penggunaan antibiotik yaitu sebesar 65,92 DDD/100 hari rawat. Penggunaan antibiotik terbesar adalah ampisilin sebesar 27,53 DDD/100 hari rawat yang dapat diartikan bahwa ada 27-28 pasien pneumonia pediatri yang mendapatkan terapi ampisilin sesuai DDD (2 gram) per hari. Lalu diikuti dengan gentamisin yaitu sebesar 8,39 DDD/100 hari rawat yang dapat diartikan ada 8-9 pasien pneumonia pediatri yang mendapatkan terapi gentamisin sesuai DDD (240 mg).

Antibiotik ampisilin merupakan rekomendasi untuk pengobatan lini pertama (first line) pada pasien pneumonia khususnya pada anak lebih dari 2 bulan atau dengan derajat pneumonia yang ringan, penggunaan antibiotik ampisilin apabila dicurigai terdapat bakteri Streptococcus pneumoniae(31). Antibiotik ampisilin merupakan antibiotik yang dianjurkan untuk terapi empirik pada anak. Sedangkan gentamisin merupakan antibiotik yang dianjurkan untuk terapi pneumonia anak dengan umur 1 bulan 18 tahun(32). Gentamisin juga banyak digunakan karna obat ini diindikasikan pemakaian nya sebagai terapi profilaksis pada neonatus yang lahir dengan resiko infeksi(12).

\section{Pola Konsumsi Antibiotik}

Tabel 5 Drug Use 90\%

\begin{tabular}{|c|c|c|c|}
\hline Antibiotik & $\begin{array}{c}\text { DDD/100 hari } \\
\text { raw at }\end{array}$ & $\begin{array}{c}\text { Persentas } \\
\text { e (\%) }\end{array}$ & $\begin{array}{c}\text { Segmen } \\
\text { DU }\end{array}$ \\
\hline Ampisilin & 27,53 & 41,76 & \multirow{5}{*}{90} \\
\hline Gentamicin & 8,39 & 12,72 & \\
\hline Azitromisin & 7,13 & 10,81 & \\
\hline Amoksisilin & 6,88 & 10,43 & \\
\hline $\begin{array}{l}\text { Ampisilin+ } \\
\text { sulbaktam }\end{array}$ & 6,6 & 10,01 & \\
\hline Cefotaxime & 6,34 & 9,61 & \multirow{3}{*}{10} \\
\hline Eritromisin & 2,6 & 3,94 & \\
\hline Ceftriakson & 0,45 & 0,68 & \\
\hline
\end{tabular}

Berdasarkan tabel 5 terdapat 8 jenis antibiotik yang digunakan pada pasien pneumonia pediatri pada tahun 2019 dengan 5 jenis antibiotik yang masuk kedalam segmen DU 90 \% penggunaan terbanyak yaitu ampisilin, gentamisin, azitromisin, amoksisilin dan ampisilin sulbaktam.

\section{Tepat Pasien}

Tabel 6 Kontraindikasi Antibiotik

$\begin{array}{cccc} & \begin{array}{c}\text { Cefotaxime/ } \\ \text { Cefadroxil/ } \\ \text { Ceftriaxone }\end{array} & \text { Gentamicin } & \text { Ampisilin/Am } \\ & \text { oxcillin }\end{array}$

Tabel 7 Ketepatan Pasien

\begin{tabular}{lccc}
\multicolumn{1}{c}{ Antibiotik } & Jumlah & \multicolumn{2}{c}{ Keterangan } \\
\cline { 3 - 4 } & & Tepat & $\begin{array}{c}\text { Tidak } \\
\text { tepat }\end{array}$ \\
\hline Gentamicin & 24 & $\sqrt{ }$ & - \\
\hline Ampisilin & 22 & $\sqrt{ }$ & - \\
\hline Cefotaxime & 20 & $\sqrt{ }$ & - \\
\hline Ampisilin & 19 & $\sqrt{ }$ & - \\
sulbaktam & & & - \\
\hline Amoksisilin & 8 & $\sqrt{ }$ & - \\
\hline Azitromisin & 8 & $\sqrt{ }$ & - \\
\hline Eritromisin & 3 & $\sqrt{ }$ & - \\
\hline Ceftriaxon & 1 & $\sqrt{ }$ & 0
\end{tabular}

Berdasarkan tabel diatas didapatkan hasil ketepatan pasien yaitu 100\%, penggunaan antobiotik tersebut tepat pasien karna tidak ada kontraindikasi dengan keadaan pasien. Penggunaan antibiotik golongan sefalosporin yang diberikan yaitu cefotaxim dan ceftriaxone tidak kontraindikasi terhadap kondisi pasien karena pasien tidak mengalami hipersensitifitas terhadap sefalosporin dan pada golongan penicillin yang diberikan adalah ampicillin dan amoxicillin, tidak terjadi kontraindikasi karena pasien tidak mengalami hipersensitifitas terhadap penicillin, sedangkan pada gentamicin juga tidak 
menimbulkan kontraindikasi terhadap pasien karena pasien tidak mengalami Myasthenia gravis(11).

\section{Tepat Dosis}

Tabel 8 Ketepatan Dosis

\begin{tabular}{cccc} 
Kategori & Keterangan & Jumlah & $\begin{array}{c}\text { Persentase } \\
(\mathbf{n = 7 0 )}\end{array}$ \\
\hline $\begin{array}{c}\text { Besaran } \\
\text { Dosis }\end{array}$ & Dosis lebih & 15 & $21,42 \%$ \\
\cline { 2 - 4 } & Dosis kurang & 15 & $21,42 \%$ \\
\hline Tepat dosis & Tepat & 40 & $57,14 \%$
\end{tabular}

Berdasarkan tabel diatas penggunaan antibiotik yang tepat dosis adalah ketepatan pemberian antibiotik sesuai dengan besarnya dosis dan frekensi pemberian yaitu sebanyak 40 pasien $(57,14 \%)$ tepat dosis. Ketidaktepatan dosis karna dosis berlebih sebanyak 15 kasus $(21,42 \%)$ dan besaran dosis yang kurang sebanyak 15 kasus $(21,42 \%)$. Ketidaktepatan pemberian antibiotik dapat mengakibatkan penyakit tidak sembuh, resiko meningkatnya efek samping, resistensi bakteri dan dapat meningkatkan biaya pengobatan(14).

\section{Tepat Interval Waktu Pemberian}

Tabel 9 Ketepatan Interval Waktu Pemberian

\begin{tabular}{cccc} 
Kategori & Keterangan & Jumlah & $\begin{array}{c}\text { Persentase } \\
(\mathbf{n = 7 0 )}\end{array}$ \\
\hline \multirow{2}{*}{ Frekuensi } & Frekuensilebih & 0 & $0 \%$ \\
\cline { 2 - 4 } & $\begin{array}{c}\text { Frekuensi } \\
\text { kurang }\end{array}$ & 0 & $0 \%$ \\
\hline Tepat & Tepat & 70 & $100 \%$ \\
Interval & & &
\end{tabular}

Berdasarkan tabel diatas, penggunaan antibiotik yang tepat interval wktu pemberian adalah ketepatan pemberian antibiotik sesuai dengan besarnya frekensi pemberian yaitu sebanyak 70 pasien (100\%). Frekuensi penggunaan yang semakin tinggi akan meningkatkan jumlah dosis (gram) antibiotika yang diterima oleh pasien, yang juga akan meningkatkan nilai DDD(15).

\section{Tepat Indikasi}

Tepat indikasi merupakan kesesuaian pemberian antibiotik dengan indikasi atau gejala adanya diagnosa pneumonia. Seluruh pasien $(100 \%)$ tepat indikasi karena semua pasien yang didiagnosis pneumonia mendapat terapi antibiotik. Antibiotik yang digunakan pada terapi pneumonia pediatri di instalasi rawat inap RSUD Dr. A. Dadi Tjokrodipo tahun 2019 yaitu gentamicin, ampisilin, cefotaxime, ampisilin sulbaktam, amoksisilin, azitromisin, eritromisin dan ceftriaxone dan telah sesuai dengan Pharmaceutical Care untuk Infeksi Saluran Pernafasan dan BNF for Children.

\section{KESIMPULAN DAN SARAN}

\section{KESIMPULAN}

Berdasarkan hasil dari penelitian ini, diperoleh kesimpulan sebagai berikut :

1. Profil demografi karakteristik pasien berdasarkan jenis kelamin yaitu diperoleh 43 pasien adalah laki-laki dan 27 pasien adalah perempuan serta karakteristik pasien berdasarkan usia diperoleh hasil sebanyak 46 pasien bayi, 20 pasien anak dan 4 pasien remaja.

2. Pola penggunaan antibiotik untuk pasien pneumonia pediatri di instalasi rawat inap RSUD Dr. A. Dadi Tjokrodipo tahun 2019 yang terbanyak adalah penggunaan gentamicin sebanyak 24 kasus $(34,28 \%)$.

3. Terdapat 8 jenis antibiotik yang digunakan pada pasien pneumonia pediatri di instalasi rawat inap RSUD Dr. A. Dadi Tjokrodipo pada tahun 2019 dengan 5 jenis antibiotik yang masuk kedalam segmen DU $90 \%$ penggunaan terbanyak yaitu ampisilin, gentamisin, azitromisin , amoksisilin dan ampisilin sulbaktam.

4. Ketepatan penggunaan antibiotik dengan kriteria 4T berdasarkan acuan standar Phamrmaceutical 
Care untuk Infeksi Saluran

Pernafasan tahun 2005 dan British

National Formulation 2011-2012 untuk kasus pneumonia pediatri di instalasi rawat inap RSUD Dr. A. Dadi Tjokrodipo periode tahun 2019 diperoleh ketepatan pasien sebanyak $100 \%$, ketepatan indikasi sebanyak $100 \%$, ketepatan dosis sebanyak $57,4 \%$ dan ketepatan interval waktu pemberian sebanyak $100 \%$.

\section{SARAN}

Berdasarkan kesimpulan diatas, peneliti memberi saran sebagai berikut untuk Peneliti selanjutnya sebiknya menggunakan metode prospektif karena penelitian menggunakan retrospektif salah satu kelemahan nya apabila terjadi kesalahan dalam pemberian antibiotik kepada pasien tidak dapat dicegah oleh peneliti atau pihak yang berwenang.

\section{UCAPAN TERIMAKASIH}

Terimakasih kepada seluruh pihak Universitas Tulang Bawang Lampung dan RSUD Dr. A. Dadi Tjokrodipo Bandar Lampung yang telah membantu dalam menyelesaikan penelitian.

\section{DAFTAR PUSTAKA}

1. [WHO] World Health Organization. 2019. Pneumonia. Geneva : WHO News Letters.

2. [Kemenkes RI] Kementrian Kesehatan Republik Indonesia. 2018. Riset Kesehatan Dasar (RISKESDAS). Jakarta.

3. [WHO] World Health Organization. 2014. Pneumonia. Geneva : WHO News Letters.

4. Farida, Yeni. 2017. Studi Penggunaan Antibiotik Pada Pasien Pneumonia di Rumah Sakit Rujukan Daerah Surakarta. Surakarta : Journal of Pharmaceutical Science and Clinical Research

5. Kementerian Kesehatan Republik Indonesia. 2011. Modul Penggunaan
Obat
Rasional.
Jakarta
Departemen Kesehatan RI.

6. Utsman, Panji. 2016. Evaluasi Penggunaan Antibiotika Pada Balita Penderita Pneumonia di Instalasi Rawat Inap RSUD Tidar Kota Magelang tahun 2016. Magelang: Universitas Muhammadiyah Surakarta.

7. [WHO] World Health Organization. 2013. Pocket Book on Hospital Care for Chlidren Guidelines for The Management of Common Childhood Illnesses, Second Edition. Switzerland: WHO Press.

8. Hartati, Susi. Rigustia, R. Zeffira, L. Vani, AT. 2019. Faktor Resiko yang Berhubungan dengan Kejadian Pneumonia pada Balita di Puskesmas Ikur Koto Kota Padang. Padang : Health and Medical Journal

9. Bradley JS, et al. 2011. Executif summary: The Management of Community-Aquired Pneumonia. Amerika: Society America.

10. Cahyaningrum, Jessica. 2018. Evaluasi penggunaan antibiotik pada pasien pneumonia pediatri di instalasi rawat inap RSUD Dr. Moewardi Surakarta tahun 2017. Surakarta : Universitas Setia Budi.

11. BMJ. 2011. BNF for Children 20112012. London : BMJ Group, Pharmaceutical Press and RCPH Publications Ltd.

12. Fitriani, Victroia Yulita. 2011. Studi Penggunaan Antibiotik pada Neonatus di NICU RSAL Dr. Ramelan Surabaya. Samarinda : Journal of Tropical Pharmacy and Chemistry.

13. Kementerian Kesehatan RI. 2012. Modul Tatalaksana Pneumonia. Jakarta : Departemen Kesehatan.

14. Virgiandhy, Nurmala. Andriana. Liana, Delima. 2015. Resistensi Dan Sensitivitas Bakteri Terhadap Bakteri Di RSU Dr. Soedarso Pontinak Tahun 2011-2013. Pontianak : eJournal Kedokteran Indonesia (eJKI). 
15. World Health Organization. 2012. Guidelines for ATC Classification and DDD Assignment 2013. Oslo : WHO Collaborating Centre for Drug Statistics Methodology. 